\title{
Importance of Ecological Awareness in Sustainability: Example of Siirt University Faculties of Agriculture and Education
}

\author{
Altuntas Arzu $^{1 *}$, Cengiz Mustafa ${ }^{2}$
}

\author{
${ }^{1}$ Department of Landscape Achitecture, Siirt University, Turkey \\ ${ }^{2}$ Department of Mathematics and Physical Sciences Education, Siirt University, Turkey \\ ${ }^{*}$ Corresponding author
}

\begin{abstract}
The change of lifestyles and the increase of environmental / ecological problems from day by day are the important issues on a global scale. Developing the ecological awareness of the individuals who are commonwealth is an important step in solving these problems. For this reason, today, almost every stage of education of the new generation (from kindergarten to university) is given importance to ecological knowledge and it is tried to transfer this knowledge to life styles. The aim of this study is to determine and compare ecological awareness levels in undergraduate departments with ecology education and to evaluate the change of this awareness according to socio demographic characteristics. For this purpose, an ecological awareness survey was applied to 209 students who received undergraduate education at the Faculties of Agriculture and Education at Siirt University. The survey results were analyzed with SPSS (Statistical Package for Social Sciences) 20.0 package program using t-test and ANOVA test. According to the results of the analysis, there was no significant difference between the two faculty students in terms of ecological awareness. . In other words, according to the survey results, there is an ecological awareness in both groups. . But this awareness does not make a difference between each other. The results obtained from the research reveal the importance of ecological awareness and living with ecological consciousness for the solution of problems such as environmental problems, damage to nature and limited natural resources.
\end{abstract}

Keywords - sustainability, environment, ecological awareness, faculty of agriculture, faculty of education, Siirt University

\section{INTRODUCTION}

Since the existence, human provided everything from the nature and has lived as part of the nature. Over time, reasons such as the advancement of technology and population growth have pushed people to tend to dominate nature and shape it in line with their wishes and needs. This situation has caused nature to change by human hands over time. Nature has been rapidly destroyed and problems have begun to arise.

With the realization of this situation, human tried to compensate for the destruction he gave to nature and the environment by using the technology he produced. But most of time this has not been possible. Environmental problems such as pollution of air and water, decreasing water resources, gradual disappearance of plant and animal species, and degradation of nature have caused people to pay more attention to this issue. As a result, a number of national and international organizations were established, agreements were signed and new policies started to be produced. In addition, environmental education has been started for children and young people, - from pre-school education to the end of university education-, in order to increase ecological knowledge

and awareness. How much natural resources are used by humans has gained an even more measurable quality with the concept of ecological footprint. In this context, creating ecological awareness has become an important environmental education tool in raising individuals with conscious consumer identity. There are national $[1,2,3$, $4,5,6,7,8]$ and international $[9,10,11,12,13,14,15$, $16,17]$ studies on this subject.

The aim of this study is to determine the ecological awareness levels of the students who have ecology education in the example of the Faculty of Agriculture and 
Education of Siirt University, to determine the levels of ecological awareness and to evaluate them comparatively.

\section{MATERIALS AND METHODS}

\subsection{Material}

The main material of the study consists of survey answers of 127 students who have undergraduate education at Faculty of Agriculture and 82 students who have undergraduate education at the Faculty of Education of Siirt University. The common feature of all these students is that they have taken or are taking ecology lessons during their undergraduate education. The survey consists of two parts. In the first part, there are questions about demographic features. In the second part, there are questions about ecological awareness (Table 1). In addition, relevant articles, theses, reports and other written / visual sources were used as materials.

Table 1. Survey questions [18]

\begin{tabular}{|c|c|c|c|c|c|c|}
\hline & & 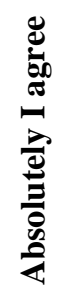 & تِّ & 匏 & 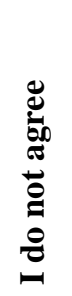 & 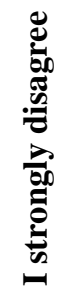 \\
\hline 1 & I do not consume foods produced out of season. & & & & & \\
\hline 2 & I eat mostly fruits and vegetables rather than animal foods. & & & & & \\
\hline 3 & I feed on fast food or ready-made food. & & & & & \\
\hline 4 & In food shopping, I do not get more than I need. & & & & & \\
\hline 5 & I use products that are produced where I live or close to where I live. & & & & & \\
\hline 6 & When shopping for food, I do not prefer products brought from abroad. & & & & & \\
\hline 7 & I do not buy plastic bags and containers in processed foods. & & & & & \\
\hline 8 & I feed on organic farming products. & & & & & \\
\hline 9 & $\begin{array}{l}\text { As overspeeding in transportation vehicles will increase fuel consumption, } \\
\text { it is harmful for the environment. }\end{array}$ & & & & & \\
\hline 10 & When I drive, I use it at a constant speed with little braking. & & & & & \\
\hline 11 & $\begin{array}{l}\text { Houses with large areas of use are more environmentally hazardous as they } \\
\text { will take up more space. }\end{array}$ & & & & & \\
\hline 12 & I prefer materials that will harm the environment least in home decoration. & & & & & \\
\hline 13 & $\begin{array}{l}\text { I design the places I live according to the low number of individual areas } \\
\text { and the high number of common areas. }\end{array}$ & & & & & \\
\hline 14 & $\begin{array}{l}\text { I think that living in detached houses is harmful to the environment due to } \\
\text { the excess usage of the area. }\end{array}$ & & & & & \\
\hline 15 & In heating, I use the least energy / clean energy sources. & & & & & \\
\hline 16 & When the air conditioner works, I close the windows. & & & & & \\
\hline 17 & $\begin{array}{l}\text { When the boiler is open in winter, I do not leave the windows open for a } \\
\text { long time. }\end{array}$ & & & & & \\
\hline 18 & I do not leave the refrigerator door open for a long time. & & & & & \\
\hline & $\begin{array}{l}\text { I use machines, refrigerators, heaters and bulbs that consume less } \\
\text { electricity in homes. }\end{array}$ & & & & & \\
\hline 20 & $\begin{array}{l}\text { I prefer to use double glazed windows in terms of thermal insulation in } \\
\text { buildings. }\end{array}$ & & & & & \\
\hline & $\begin{array}{l}\text { I prefer using a compact fluorescent bulb (CFL) instead of a traditional } \\
\text { bulb to light my house. }\end{array}$ & & & & & \\
\hline
\end{tabular}


22 I do not leave technological tools such as television and computers unnecessarily open.

23 I do not operate appliances such as dishwashers and washing machines before they are full.

24 When I am not at home for a long time, I turn off the boilers and heaters etc.

25 I do not leave electrical appliances such as phones and computers on charge for a long time.

26 It is beneficial for the environment to make public buildings and houses where the solar energy (light and heat) is used.

27 When I do not use electrical devices such as computers, televisions, music players, I do not keep it in sleep mode, I turn it off completely.

28 If possible, I recycle old / scrap electronic devices (electronic waste), batteries, batteries, etc.

29 I prefer to pay my bills on the internet, as it will save paper.

30 I can recycle recyclable domestic wastes from waste, and recycle them if possible.

31 I don't throw the leftover food in the trash.

32 I prefer a reusable cloth bag, net or basket instead of plastic bags that are used once in shopping.

33 I think that it is more beneficial for the environment to evaluate plastic coated and decorated goods in different ways by not disposing the packaging.

34 I prefer rechargeable ones when buying batteries.

35 I separate packaging wastes (glass, tin, plastic, paper) and I try to recycle them.

36 If house cleaning is not necessary, I prefer wiping instead of washing.

37 I do not use cleaning materials more than necessary.

38 In terms of water saving, I think that the toilet flushes with dual structure should be used according to the small ablution-large ablution separation.

39 To avoid wasting water, I do not operate the dishwasher and washing machine before it is full.

40 Methods such as limiting the shower time, turning off the water while brushing teeth, shaving, not washing the car with a hose, and reducing carpet washing in homes save water.

\subsection{Method}

The ecological awareness scale developed by Coskun [18] was used in the research method. In the second part of the survey, the ecological awareness part, the scale consists of five factors. Variance explanation rates of the factors: energy is $10.9 \%$; waste is $9.41 \%$; food is $9.17 \%$; water consumption is $7.65 \%$ and transportation and shelter is $6.28 \%$. The total variance rate is $43.42 \%$ [18]. The internal reliability alpha coefficients of the factors are: Energy 0.90, Waste 0.90, Food 0.89, water consumption 0.79, transportation and accommodation 0.89 . The 5-point likert rating ( $1=$ strongly disagree, $5=$ strongly agree $)$ consists of 40 expressions. 8 of the statements are "Food", 6 are
"Transportation and shelter", 13 are "Energy", 8 are "Waste" and 5 are "Water consumption" sub-dimensions. The minimum score that can be obtained from the whole scale is $40(40 \times 1)$ and the maximum score is $200(40 \times 5)$. A high score indicates a high level of awareness. The data obtained from the questionnaires were analyzed in SPSS 20.0 package program. In this context, firstly, Cronbach Alpha reliability test and Skewness - Kurtosis tests were performed to the questions. Then, t-test and one-way ANOVA test were applied to the data obtained, and the Tukey test was chosen as the post-hoc test. 


\section{RESULTS}

\subsection{Demographic Features of Participants}

The demographic characteristics of the participants studying at Siirt University Faculty of Agriculture and participating in the research are given in Table 2 . Accordingly, $43.3 \%$ of the participants are women and $56.7 \%$ are men. $15.0 \%$ of them spent most of their lives in villages and towns, $20.5 \%$ in districts, $43.3 \%$ in cities and $21.3 \%$ in metropolitan cities. The monthly expenditure of $15.7 \%$ of the participants is $0-500 \mathrm{TL}$, the monthly expenditure of $41.7 \%$ is $500-1000 \mathrm{TL}$, and the monthly

Table 2. Demographic characteristics of the participants studying at Siirt University Faculty of Agriculture

\begin{tabular}{|c|c|c|c|}
\hline Demograhic charcteristics & Parameters & Frequency & Percentage \\
\hline \multirow{2}{*}{ Gender } & Female & 55 & 43,3 \\
\hline & Male & 72 & 56,7 \\
\hline \multirow{4}{*}{ The longest lived place } & Village & 19 & 15,0 \\
\hline & District & 26 & 20,5 \\
\hline & City & 55 & 43,3 \\
\hline & Metropolis & 27 & 21,3 \\
\hline \multirow{4}{*}{ Monthly average expenditure } & $0-500 \mathrm{TL}$ & 20 & 15,7 \\
\hline & $500-1000 \mathrm{TL}$ & 53 & 41,7 \\
\hline & $1000-1500 \mathrm{TL}$ & 13 & 10,2 \\
\hline & $1500 \mathrm{TL}$ and above & 41 & 32,2 \\
\hline \multirow{5}{*}{ Mother's educational status } & Primary school & 60 & 47,2 \\
\hline & Secondary school & 19 & 15,0 \\
\hline & High school & 13 & 10,2 \\
\hline & Undergraduate / graduate & 4 & 3,1 \\
\hline & Illiterate & 31 & 24,4 \\
\hline \multirow{5}{*}{ Father's educational status } & Primary school & 37 & 29,1 \\
\hline & Secondary school & 31 & 24,4 \\
\hline & High school & 30 & 23,6 \\
\hline & Undergraduate / graduate & 17 & 13,4 \\
\hline & Illiterate & 12 & 9,4 \\
\hline
\end{tabular}

The demographic characteristics of the participants studying in the Siirt University Faculty of Education and participating in the research are given in Table 3. Accordingly, $64.7 \%$ of the participants are women and $35 \%$ are men. $35.3 \%$ of them spent most of their lives in villages and towns, $19.5 \%$ in districts, $29.3 \%$ in cities and $1.9 \%$ in metropolitan cities. The monthly expenditure of $39.0 \%$ of the participants is $0-500 \mathrm{TL}$, the monthly expenditure of $42.7 \%$ is $500-1000 \mathrm{TL}$, and the monthly expenditure of $32.2 \%$ is $1500 \mathrm{TL}$ and above. The mother of $62.2 \%$ of the participants graduated from primary and secondary schools, $10.2 \%$ from high schools, $3 \%$ from undergraduate and graduate degrees. The rate of illiterate mothers is $24.4 \%$. The father of $53.5 \%$ of the participants graduated from primary and secondary schools, $23.6 \%$ from high schools and $13.4 \%$ from undergraduate and graduate degrees. The rate of illiterate fathers is $9.4 \%$. 
International Journal of Environment, Agriculture and Biotechnology, 5(3)

May-Jun, 2020 / Available: https://ijeab.com/

Table 3. Demographic characteristics of the participants studying at the Faculty of Education at Siirt University

\begin{tabular}{|c|c|c|c|}
\hline Demograhic charcteristics & Parameters & Frequency & Percentage \\
\hline \multirow{2}{*}{ Gender } & Female & 53 & 64,7 \\
\hline & Male & 29 & 35,3 \\
\hline \multirow{4}{*}{ The longest lived place } & Village & 29 & 35,3 \\
\hline & District & 16 & 19,5 \\
\hline & City & 24 & 29,3 \\
\hline & Metropolis & 13 & 15,9 \\
\hline \multirow{4}{*}{ Monthly average expenditure } & $0-500 \mathrm{TL}$ & 32 & 39,0 \\
\hline & $500-1000 \mathrm{TL}$ & 35 & 42,7 \\
\hline & $1000-1500 \mathrm{TL}$ & 1 & 13,4 \\
\hline & $1500 \mathrm{TL}$ and above & 4 & 4,9 \\
\hline \multirow{5}{*}{ Mother's educational status } & Primary school & 36 & 43,9 \\
\hline & Secondary school & 4 & 4,9 \\
\hline & High school & 5 & 6,1 \\
\hline & Undergraduate / graduate & 5 & 6,1 \\
\hline & Illiterate & 32 & 39,0 \\
\hline \multirow{5}{*}{ Father's educational status } & Primary school & 26 & 31,7 \\
\hline & Secondary school & 19 & 23,2 \\
\hline & High school & 15 & 18,3 \\
\hline & Undergraduate / graduate & 13 & 15,9 \\
\hline & Illiterate & 9 & 11,0 \\
\hline
\end{tabular}

\subsection{Question analysis, reliability and normality}

Reliability among the five sub-dimensions of the ecological awareness scale and questions were analyzed with Cronbach Alpha values. Cronbach Alpha analysis values are interpreted as in Table 4. In this study, Cronbach
Alpha reliability values of the questions are between 0.79 and 0.90 and it is seen that the consistency is high enough (Table 5).

Table 4. Reliability analysis values [19]

\begin{tabular}{c|c}
\hline Cronbach Alpha reliability coefficient & Comment \\
\hline$\geq 0.9$ & Excellent \\
$0.7 \leq \alpha \leq 0.9$ & Good \\
$0.6 \leq \alpha \leq 07$ & Acceptable \\
$0.5 \leq \alpha \leq 0.6$ & Weak \\
$\alpha<0.5$ & Unacceptable \\
\hline
\end{tabular}

Table 5. Ecological awareness scale $\alpha$ reliability table

\begin{tabular}{ccc}
\hline Sub dimensions & Number of questions & $\boldsymbol{\alpha}$ \\
\hline Food & 8 & .89 \\
Transport and shelter & 6 & .89 \\
Energy & 13 & .90 \\
Wastes & 8 & .90 \\
Water consumption & 5 & .79 \\
TOTAL & $\mathbf{4 0}$ & $\mathbf{. 9 0}$ \\
\hline
\end{tabular}


Within the scope of normality analyzes, Skewness kurtosis analysis is based on +1 and -1 as limit values [20]. Skewness - kurtosis values of ecological awareness dimensions are given in Table 6. As can be seen from the table, the dimensions have a normal distribution. This shows that the analyzes to be performed are suitable for the t test.

Table 6. Ecological awareness dimensions Skewness - kurtosis values

\begin{tabular}{ccc}
\hline Sub dimensions & Skewness & Kurtosis \\
\hline Food & -.248 & -.240 \\
Transport and shelter & -.313 & -.071 \\
Energy & 0.979 & 1.115 \\
Wastes & .550 & -.006 \\
Water consumption & .868 & .397 \\
TOTAL & $\mathbf{. 3 7 2}$ & $\mathbf{. 1 2 7}$ \\
\hline
\end{tabular}

\subsection{Ecological awareness dimensions descriptive statistics}

\subsubsection{Descriptive statistics of the Faculty of Agriculture participants}

The ranges and averages of the dimensions of the ecological awareness scale calculated for the participants of the Faculty of Agriculture are presented in Table 7. average $(X=22.96)$, average of wastes $(X=15.64)$ and water consumption $(X=9.05)$. The ecological awareness average of the individuals is $(\mathrm{X}=72,58)$. This situation can be explained by the fact that the level of participation of individuals in expressions on the scale has a value between "I am indecisive" and "I agree", but it is relatively closer to "I am indecisive".

As seen in Table 7 , food average $(X=19.83)$, transportation and shelter average $(X=12.31)$, energy

Table 7. Descriptive statistics of the ecological awareness dimensions regarding the participants of the Faculty of Agriculture

\begin{tabular}{|c|c|c|c|c|c|}
\hline Sub dimensions & $\mathbf{N}$ & Min. & Max. & $\mathbf{X}$ & Std. Dev. \\
\hline Food & 127 & 11,13 & 27,38 & 19,8353 & 3,47479 \\
\hline $\begin{array}{c}\text { Transport and } \\
\text { shelter }\end{array}$ & 127 & 5,17 & 22,83 & 12,3122 & 3,51701 \\
\hline Energy & 127 & 12,08 & 55,23 & 22,9600 & 8,40895 \\
\hline Wastes & 127 & 7,13 & 33,38 & 15,6417 & 6,01592 \\
\hline $\begin{array}{c}\text { Water } \\
\text { consumption }\end{array}$ & 127 & 4,20 & 21,00 & 9,0520 & 4,06746 \\
\hline TOTAL & 127 & 38,33 & 122,63 & 72,5816 & 16,54884 \\
\hline
\end{tabular}

Whether there is a relationship between gender variable and awareness dimensions was analyzed by $\mathrm{t}$ test. According to the results of the analysis, the answers between gender and dimensions have a homogeneous distribution. However, there was no significant relationship between them based on the $95 \%$ confidence interval ( $p>$ $0.05)$.

The participants were divided into four groups according to where they live most, namely village-town, district, city and metropolis. Although the groups were homogeneously distributed, no significant relationship was found between the longest lived place and awareness dimensions ( $\mathrm{p}$ > 0.05). In the analysis of all dimensions, post-hoc test (Tukey test) was not performed since the $\mathrm{P}$ value was greater than 0.05 .

Likewise, the participants were divided into four groups as “0-500 TL, 500-1000 TL, 1000-1500 TL, 1500 TL and 
above" according to their average monthly expenditures. The groups were distributed homogeneously, but since the $\mathrm{P}$ values obtained as a result of the ANOVA test analysis were greater than 0.05 , there was no significant relationship between average monthly expenditure and ecological awareness ( $p>0.05)$. This situation is the same in terms of mother education level, father education level and ecological awareness relation, and no significant relationship was found ( $\mathrm{p}>0.05)$.

\subsubsection{Descriptive statistics of the Faculty of Education participants}

The ranges and averages of the dimensions of the ecological awareness scale calculated for the participants of the Faculty of Education are given in Table 8.

Table 8. Ecological awareness dimensions descriptive statistics regarding the Faculty of Education participants

\begin{tabular}{c|r|r|r|r|r}
\hline Sub dimensions & $\mathbf{N}$ & Min. & Max. & \multicolumn{1}{c}{ X } & \multicolumn{1}{c}{ Std. Dev. } \\
\hline Food & 82 & 10,13 & 29,63 & 20,2088 & 3,75247 \\
Transport and & & 52 & 25,83 & 13,0346 & 3,36281 \\
shelter & & 5,17 & 47,23 & 24,9315 & 8,18786 \\
Energy & 82 & 12,08 & 29,63 & 16,5442 & 4,96995 \\
Wastes & 82 & 7,13 & 20,00 & 9,3390 & 3,54160 \\
Water & 82 & 4,20 & 115,36 & 76,5869 & 15,43559 \\
consumption & & & & \\
TOTAL & 82 & 35,33 & & & \\
\hline
\end{tabular}

As seen in Table 8, food average $(X=20.20)$, transportation and shelter average $(X=13.03)$, energy average $(X=24.93)$, average of wastes $(X=16.54)$ and water consumption $(\mathrm{X}=9.33)$. The ecological awareness average of the individuals is $(\mathrm{X}=76.58)$. This situation can be explained by the fact that the level of participation of individuals in expressions on the scale has a value between "I am indecisive" and "I agree", but it is relatively closer to "I am indecisive".

Whether there is a relationship between gender variable and awareness dimensions was analyzed by $t$ test. According to the results of the analysis, the answers between gender and dimensions have a homogeneous distribution. However, there was no significant relationship between them based on the $95 \%$ confidence interval ( $p>$ $0.05)$.

The participants were divided into four groups according to where they live most, namely village-town, district, city and metropolis. Although the groups were homogeneously distributed, no significant relationship was found between the longest lived place and awareness dimensions ( $p>$ 0.05). In the analysis of all dimensions, post-hoc test (Tukey test) was not performed since the $\mathrm{P}$ value was greater than 0.05 .

Likewise, the participants were divided into four groups as "0-500 TL, 500-1000 TL, 1000-1500 TL, 1500 TL and above" according to their average monthly expenditures. The groups were distributed homogeneously, but since the ISSN: 2456-1878
$\mathrm{P}$ values obtained as a result of the ANOVA test analysis were greater than 0.05 , there was no significant relationship between average monthly expenditure and ecological awareness ( $p>0.05)$. This situation is the same in terms of mother education level, father education level and ecological awareness relation, and no significant relationship was found ( $\mathrm{p}>0.05)$.

\subsection{Comparison of ecological awareness of students studying in Siirt University Faculty of Agriculture and Education}

Whether there is a relationship between faculty variable and awareness dimensions in determining the ecological awareness of the two groups was analyzed by test. According to the results of the analysis, the answers between faculties and awareness dimensions have a homogeneous distribution. However, there was no significant relationship between them based on the $95 \%$ confidence interval ( $\mathrm{p}>0.05)$.

\section{CONCLUSION}

As can be seen from the literature reviews, there are many studies conducted on different scales on ecology and ecological awareness issues. However, researches where the subject is used as an educational tool in environmental education are not sufficient. With this study, ecological awareness levels of individuals who have received or are 
studying ecology and the integration of ecology issues into their lives were investigated.

According to the results of the research, there was no significant relationship between the students studying in two different faculties. It is very important for individuals to receive ecology education in order to create ecological awareness in their lives, but it is even more important that they incorporate this training into their lives.

Ecological awareness is great importance in the world where nature and natural resources are exhausted, living spaces become more and more restricted over time and life becomes increasingly difficult. In order to leave a livable world and a better living space for future generations, it is necessary to live in a nature-oriented way [21]. This is an inevitable fact of sustainability and living in a sustainable world.

\section{REFERENCES}

[1] Distan, H. (1999). The Place and Importance of Education in the Formation of Environmental Protection Awareness and Sensitivity (The Case of Turkey) (Master Thesis). Gazi University Institute of Educational Sciences, Ankara-Turkey (In Turkish).

[2] Cabuk B., Karacaoglu O. (2003). Investigation of Environmental Responsibilities of University Students. Ankara University Faculty of Educational Sciences Journal, 36: 189-198 (in Turkish).

[3] Atasoy E., Erturk H. (2008). A Field Research on Primary School Students' Environmental Attitude and Environmental Knowledge. Erzincan Eğitim Fakültesi Dergisi 10(1): 105122 (in Turkish)

[4] Ertekin P. (2012). The effect of environmental education practices on sustainable resource use on primary school students' awareness of carbon footprint (Master Thesis). Muğla Sitkı Koçman University Institute of Educational Sciences, p. 135, Muğla-Turkey (In Turkish).

[5] Cetin F.A. (2015). The effect of ecological footprint training on 8th grade students' attitude, awareness and behavior level towards sustainable life (Master Thesis). Gazi University Institute of Educational Sciences, p 165, Ankara-Turkey (In Turkish).

[6] Akkor O. (2018). Application and Evaluation of the Ecological Footprint as a Tool of Environmental Education for Sustainable Life. TRNC Near East University Institute of Educational Sciences Environmental Education and Management, Doctoral Thesis, (in Turkish)

[7] Arıca S.C., Kagar C. (2018). The Key to Leaving a Livable World for Future Generations: Ecological Literacy. Responsible Production and Consumption, 1 (2), 31-42, (in Turkish)

[8] Asik, N.A. (2018). Environmental Attitudes and Behaviors of Students Receiving Tourism Education at Associate's Level. Journal of Social and Humanities, (10)2, ISSN: 13098012

[9] Flint K. (2001). Institutional Ecological Footprint Analysis A Case Study of the University of Newcastle, Australia. International Journal of Sustainability in Higher Education, $2(1), 48-62$.
[10] Anderle K. (2002). Integrating Life Cycle Analysis and Ecological Footprint Calculator to Foster Sustainable Behaviors. MS Thesis, University of North Texas.

[11] Bond S. (2003). Ecological Footprinting: Comparing Nature's Supply with Human Demand. Ecological Footprinting. WWF Cymru.

[12] Rees E.W. (2003). Impeding Sustainability? The Ecological Footprint of Higher Education. Planning for Higher Education, 31 (3), 88-89.

[13] Meyer V. (2004). The Ecological Footprints as an Enviromental Education Tool for Knowledge, Attitude and Behaviour Changes Towards Sustainable Living MS Thesis, University of South Africa.

[14] Knaus M., Löhr D., Bernadette O. (2005). Valuation of Ecological İmpacts- A Regional Approach Using the Ecological Footprint Concept. Enviromental Impact Assesment Review, June, 12-18.

[15] Ryu H.C., Brody D.S. (2006). Examining the Impacts of a Graduate Course on Sustainable Development Using Ecological Footprint Analysis. International Journal of Sustainability in Higher Education, 7 (2), 158 - 175

[16] Klein-Banai C., Theis L.T. (2011). An urban university's ecological footprint and the effect of climate change, Ecological Indicators, 11(3), ss. 857-860.

[17] Medina M.A. P., Toledo-Bruno A.G. (2016). Ecological Footprint of University Students: Does gender matter?. Global Journal of Environmental Science and Management, 2(4), 339-344.

[18] Coskun I.C. (2013). Investigation of ecological footprint levels of clasroom teacher candidates (MS Thesis). Gazi University, Institute of Education Sciences, Departmant of Primary School Education, Ankara, 104 p.

[19] Kilic S. (2016). Cronbach's alpha reliability coefficient. Journal of Mood Disorders 6(1): 47-8.

[20] Sposito G., Juan G. (1983). A general soul volume change equation: effect of load pressure. Soil Science Society of America Journal 47(3), 422- 425.

[21] Secme D. (2019). Ecological footprint awareness:example of SDU faculty of architecture students (MS Thesis). Suleyman Demirel University, Graduate School of Natural and Applied Scences, Department of Landscape Architecture, Isparta, Turkey, 67 p. 